\title{
The relationship between childhood psychosocial stressor level and telomere length: a meta-analysis
}

\author{
Louise M. Hanssen, ${ }^{1}$ Nicola S. Schutte, ${ }^{1}$ John M. Malouff, ${ }^{1}$ Elissa S. Epel${ }^{2}$ \\ ${ }^{1}$ Department of Psychology, University of New England, Australia; ${ }^{2}$ Department of Psychiatry, \\ University of California, San Francisco, CA, USA
}

\begin{abstract}
This meta-analysis examined the association between the level of childhood psychosocial stressors and telomere length, an important health biomarker. The meta-analysis, including 27 samples and 16,238 participants, found a significant association of -0.08 between a higher level of childhood stressors and shorter telomere length at a mean age of 42 across studies. Moderator analyses showed a trend in the direction of effect sizes being significantly larger with shorter times between the stressors and telomere measurement. Moderator analyses showed significantly higher effect sizes for studies that used a categorical method for assessing child stressor level and for assays completed with qPCR rather than with the Southern blot method. There was no significant moderation of effect size by whether study assayed leukocytes or buccal cells, whether the study assessed child stressor level by memory-based recall versus archival records, and whether the study controlled for age, sex, or additional variables. The results, focused on childhood events, add to prior findings that perceived stress and negative emotions are associated with telomere length.
\end{abstract}

\begin{abstract}
Correspondence: John M. Malouff, University of New England, Armidale NSW 2351, Australia.

Tel.: +61.267733776 - Fax: +61.267742820 .

E-mail: jmalouff@une.edu.au

Key words: childhood stressors, childhood trauma, meta-analysis, telomere, telomere length.

Contributions: LMH, identified articles; coded data; wrote parts of introduction, method, and results; completed Figure 1, entered references; NSS, originated idea for the meta-analysis; checked codings; wrote final version of introduction, wrote parts of discussion; JMM, supervised entire project, checked codings, wrote final version of results and discussion, submitted manuscript; ESE, contributed idea for specific focus of the meta-analysis, provided advice about coding decisions, made suggestions about improvements to the manuscript.
\end{abstract}

Conflict of interest: the authors declare no potential conflict of interest.

Received for publication: 9 November 2016.

Accepted for publication: 30 March 2017.

This work is licensed under a Creative Commons AttributionNonCommercial 4.0 International License (CC BY-NC 4.0).

CC Copyright Lo. M. Hanssen et al., 2017

Licensee PAGEPress, Italy

Health Psychology Research 2017; 5:6378

doi:10.4081/hpr.2017.6378

\section{Introduction}

Psychosocial stressors experienced during childhood, such as maltreatment or neglect, predict an increased risk of negative health outcomes across the life span (Felitti et al., 1998; Shonkoff, Boyce, \& McEwen, 2009; Shonkoff \& Garner, 2012; Wegman \& Stetler, 2009). Experiencing high levels of childhood psychosocial stressors is associated with the later development of depression, bipolar disorder, post-traumatic stress disorder, and substance abuse, as well as cardiovascular disease, gastrointestinal disorders, metabolic disorders and respiratory problems (Green et al., 2010; Wegman \& Stetler, 2009). High levels of childhood psychosocial stressors are associated with an increased risk of premature death (Brown et al., 2009). Stressors experienced during early developmental windows may have epigenetic effects and enduring influences on biomarkers and nervous and immune system functioning (Shonkoff \& Garner, 2012). For example, high levels of childhood stressors alter physiologic, cellular, and immune stress responses (Drury et al., 2014).

Telomere length may link childhood psychosocial stressors with later health developments. Telomeres are a biomarker associated with various aspects of health (Rode, Nordestgaard, \& Bojesen, 2015). Telomeres are the nucleoprotein complexes at the end of chromosomes that preserve genetic information, regulate cellular replicative capacity, and prevent end-to-end fusion (Blackburn, Greider \& Szostak, 2006). Telomere length erosion can occur through repeated cell division and through exposure to oxidative stress and inflammation (O'Donovan et al., 2011). The general trend is for telomeres to shorten with aging; however, telomere biology is dynamic (Blackburn, Epel, \& Lin, 2015) and telomeres can lengthen as well as shorten over time (Epel, 2012). Short telomere length is associated with or predicts many of the common diseases of aging, such as cardiovascular disease, stroke, cancer, vascular dementia, osteoporosis, obesity and diabetes (Blackburn et al., 2015; Rode et al., 2015), and all-cause mortality (Rode et al, 2015).

Systematic reviews (Næss \& Kirkengen, 2015; Oliveira, et al., 2016) of studies of stressors and telomere length suggest that greater exposure to stressors may be associated with shorter telomeres. However, the evidence is mixed, with not all studies finding a significant relationship between exposure to stressors and telomere length. Exposure to stressors, which are events, may lead to greater perceived stress, a psychological phenomenon. Meta-analyses of effect sizes of the relationship across studies of perceived stress and telomere length reported a significant metaanalytic association (Schutte \& Malouff, 2014; Mathur et al., 2016). To date no meta-analysis of effect sizes of the relationship between childhood psychosocial stressors and telomere length across studies has been published. Such a meta-analytic investigation could provide an overall effect size of relationship between 
childhood psychosocial stressors and telomere length across studies and examine moderating variables that may account for differences in findings across studies. The findings of such a meta-analysis might provide information regarding mechanisms of aging and disease in relation to early-life experience.

Studies of childhood stressor level and telomere length have differed in how long after childhood stressor exposure telomere length was assessed. Some studies (e.g., Surtees et al., 2011) have related exposure to stressors in childhood to telomere length at various adult ages. Other studies (e.g., Shalev et al., 2013) have related childhood psychosocial stressors to telomere length in childhood.

Studies have varied in assessment of childhood psychosocial stress. Some studies (e.g., Kananen et al., 2010) used continuous measures of childhood trauma. Other studies compared participants in categories of amount of childhood psychosocial stressors, such as high or low exposure to stressors (e.g., Tyrka et al., 2015)

Many studies (e.g., Kananen et al., 2010) used measures relying on retrospective memory of participants or others, such as parents, of past events. Some studies (e.g., Savolainen, 2014) used archival indicators of psychosocial stressors, such as being separated from parents during a war or being in institutional care.

Studies examining the association between childhood stressors and telomere length also varied in approach to telomere length assessment. Most studies used qPCR (e.g., Chen et al., 2014), and two (Glass et al., 2010; Kielcolt-Glaser et al., 2011) used Southern blot. Most studies assessed telomere length in leucocytes (e.g., Mason et al., 2015), and some assessed telomere length in buccal cells (Küffer et al., 2016). Some studies controlled for age, gender and other variables, while others did not. Given the wide variance in methods, it is important to examine whether these differences moderate the association between stressor level and telomere length.

\section{Aims and hypotheses of the present study}

The main aim of the present study was to use meta-analysis to determine an overall effect size of the association between childhood psychosocial stressor levels and telomere length. A further aim of this study was to examine potential moderators of this association.

The main research hypothesis of this study was that greater childhood psychosocial stress levels would be associated with shorter telomere length. We also hypothesized that because the dynamic nature of telomere biology allows telomere repair (Blackburn et al., 2015), the longer the time between stressor occurrence and when the telomere measurement was taken, the lower the association would be. However, it was not possible to code each study for the time between stressor exposure and telomere assay because many studies assessed stressor level over the entirety of childhood. To test the hypothesis as clearly as feasible, we determined whether the higher the mean age at time of telomere measurement in a study, the lower would be the association between level of childhood stressors and telomere length. That was the only directional moderator hypothesis.

Coding studies by type of stressor experienced was not feasible because many studies assessed the occurrence of a wide range of types of stressors and reported results as a sum of the number of childhood stressors. However, we did record the general nature of the stressors focused on in each study, as shown in Table 1. Studies used such a variety of psychosocial stressor measures that it was not feasible to examine specific measures as potential moderators.

In exploratory analyses we examined several possible moderators of effect size with no specific hypothesis about them. We chose these potential moderators because virtually every study provided needed information about them, because the variables could possibly be related to effect size, and because at least some prior meta-analyses relating to telomere length examined them (e.g., Mathur et al., 2016; Schutte \& Malouff, 2014). These moderator variables included (1) type of tissue assayed, (2) whether the level of stressors was measured as categorical or continuous, (3) what type of assay was used, (4) whether childhood stressor level was based retrospectively on memory of events or not, whether (5) age and (6) sex were controlled, (7) whether additional variables were controlled, and (8) whether telomere length was log-transformed due to non-normal distribution of data.

\section{Literature Search}

We systematically searched PsychINFO, Pubmed, EMBASE, CINAHL Complete, Cochrane Central, Research Gate, and Google Scholar to identify all articles, completed at any time, reporting on childhood psychosocial stressors and telomere length. The search concluded in August 2016. The key words of the search included telomere and at least one of the following terms: stress/stressor/stressful, childhood, psychological, abuse, neglect, early life, and social environment. We also reviewed the reference lists of retrieved articles for potentially relevant articles that we had not captured in the database search. Finally, we attempted to contact researchers who had published relevant research findings to ask whether they had any relevant unpublished research findings.

\section{Inclusion criteria of studies in the meta-analysis}

We reviewed retrieved articles to determine whether they (1) reported an association between a level of any clear childhood psychosocial stressor and telomere length and (2) stated the sample size. We included studies that reported $r$, standardized beta, and between-groups statistics such as means and standard deviations.

\section{Excluded articles}

We excluded studies that examined the association between childhood socio-economic status (SES) and telomere length (e.g., Adams et al., 2007; Carroll, Diez-Roux, Adler \& Seeman, 2013; Cohen et al., 2013; Mitchell et al., 2014; Robertson et al., 2012; Needham et al., 2012, 2013) on the basis that SES in the studies included high as well as low status and did not focus on children in very low SES families. Thus, SES was not a pure measure of psychosocial stress level. We also excluded reports that provided the same results as a report we included in the meta-analysis: Brody, Yu, Beach \& Philibert (2015) and Révész, Milaneschi, Terprstra \& Penninx (2016). Three studies fit the inclusion criteria but did not provide the data needed for meta-analysis (Zhang et al., 2014; Robles, Carroll, Bai, Reynolds, Esquivel, \& Repetti, 2016; Theall et al., 2013). We attempted unsuccessfully to obtain the needed information from the corresponding authors.

\section{Coding process}

Coding involved recording three types of information relating to effect size: $r$ or some other statistic that indicates effect size, $N$ for the key analysis, and the direction of the association between stressor level and telomere length. Coding also included entering data for each study about the possible moderators of effect size. When studies reported results for more than one measure of level of childhood stressors, we calculated the average effect size across the measures.

Two of us completed the initial coding together. Then a third 
member of our research group independently coded the effect sizes and moderators. A comparison of the independent coding showed agreement on $95 \%$ of the decisions. For all disagreements regarding coding, we made final decisions by consensus.

\section{Relevant studies identified}

The literature search retrieved 2,122 potentially relevant articles. Figure 1 shows the study selection process that resulted in the 27 samples that met all inclusion criteria.

\section{Meta-analytic methods}

We report effect sizes below as $r$. When studies reported standardized beta weights with other variables included in the regression, we used the results that controlled for sex and age and as few other variables as possible. It is sensible to include age and sex controlled effect sizes because studies have found that women tend to have longer telomeres (Gardner et al., 2014) and that younger individuals tend to have longer telomeres (Marioni et al., 2016). Most of the studies did control for those variables, either statistically or by comparing high and low stressor groups that were very similar with regard to the variables.

The Comprehensive Meta-Analysis Program (Borenstein, Hedges, Higgins \& Rothstein, 2014) calculated the overall weighted effect size. We used a random effects model in order to allow for between-studies variation. The $\mathrm{Q}$ statistic assessed effect-size homogeneity across studies. Finally, trim and fill method and failsafe $N$ assessed the impact of possibly missing studies.

\section{Results}

Table 1 shows the key characteristics of each included sample. Figure 2 shows graphically the effect size for each sample. The overall meta-analytic association between level of childhood psychosocial stressors and telomere length, with 27 samples, including 16,238 total participants, was $r=-0.082$ (95\%CIs -0.122 , $0.042), \mathrm{P}<0.001$. There was a significant level of heterogeneity among effect sizes, $Q(26)=109, \mathrm{P}<0.001, R^{2}=76$, suggesting the possibility of finding moderators of effect size.

The fail-safe $N$ was 338 , indicating that 338 studies with 0 effect size would be needed to reduce the overall effect size to a nonsignificant level. Duval and Tweedie's trim-and-fill statistic indicated that the overall effect size was not significantly affected by the results of small $\mathrm{N}$ studies and that no adjustment in effect size was needed. See Figure 3 for the funnel plot of effect sizes.

The mean age at telomere measurement in the studies was 42 years. The only directional hypothesis regarding potential moderators of effect size, that the younger the participants at measurement of telomere length, the higher the effect size, showed a trend towards significance, slope estimate $=0.002$ (95\%CIs $0.000,0.004)$,
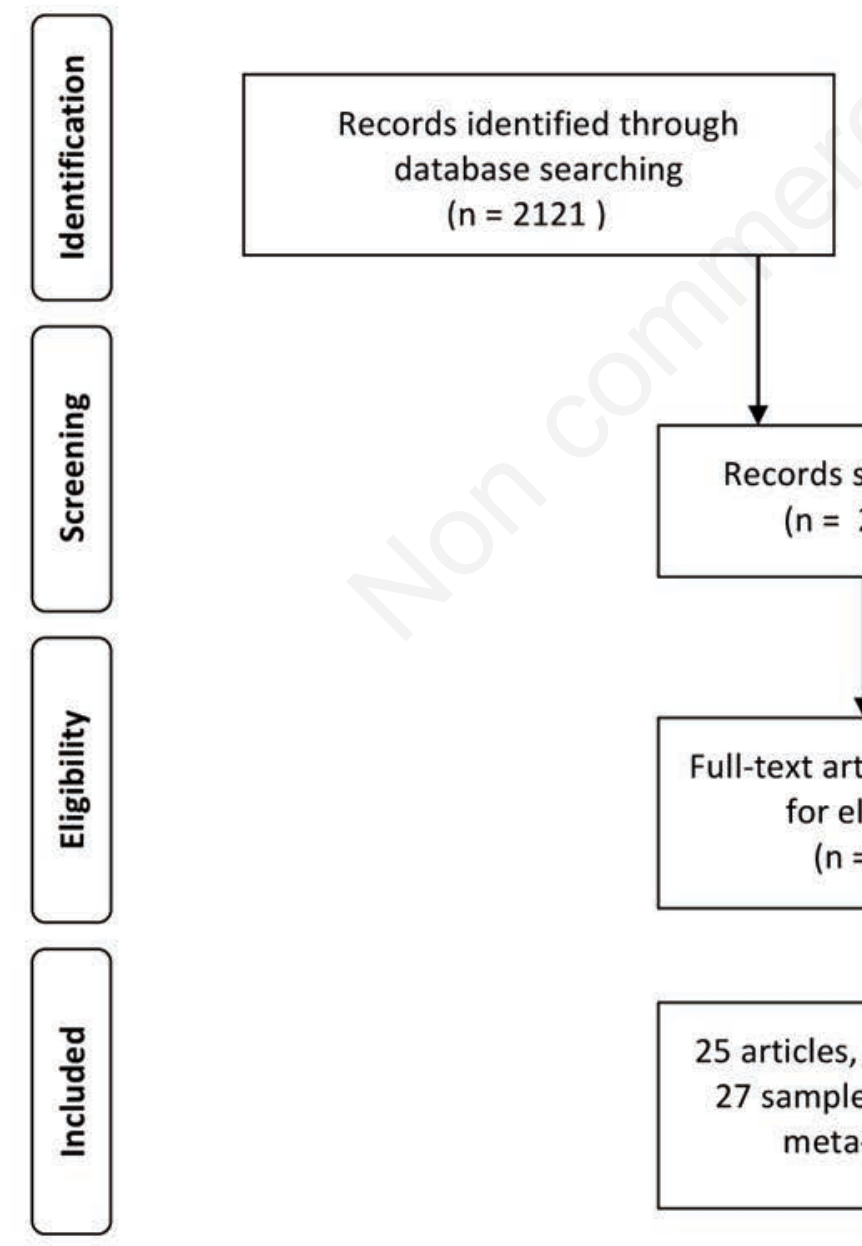

\section{Additional records identified via other methods

$$
(n=1)
$$

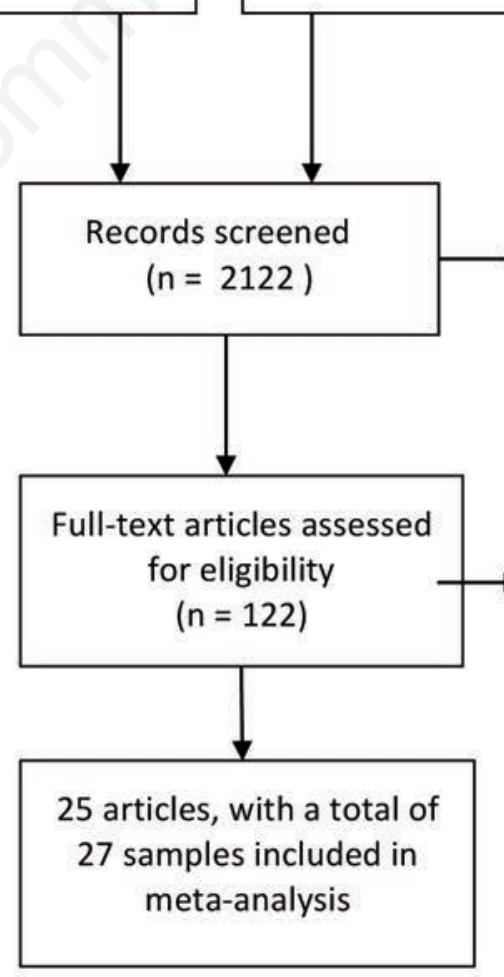

Records excluded

$(n=2000)$

Figure 1. Flowchart of article selection.

Full-text articles excluded as did not fit criteria $(n=97)$ 
Table 1. Descriptive data, including effect size, for studies in the meta-analysis.

\begin{tabular}{|c|c|c|c|c|c|c|c|c|c|c|c|c|}
\hline Author & $\begin{array}{l}\text { Childhood } \\
\text { psychosocial } \\
\text { stressor/s }\end{array}$ & No. & $\begin{array}{l}\text { Mean } \\
\text { age at } \\
\text { telomere } \\
\text { collection }\end{array}$ & $\begin{array}{l}\text { Memory-based } \\
\text { retrospective } \\
\text { assessment } \\
\text { of stressor }\end{array}$ & $\begin{array}{l}\text { TL cell } \\
\text { type }\end{array}$ & $\begin{array}{l}\text { TL assay } \\
\text { type }\end{array}$ & $\begin{array}{l}\text { Categorical } \\
\text { stressor }\end{array}$ & $\begin{array}{l}\text { Age } \\
\text { controlled }\end{array}$ & $\begin{array}{l}\text { Sex } \\
\text { controlled }\end{array}$ & $\begin{array}{l}\text { Other } \\
\text { variables } \\
\text { controlled } \\
\text { for }\end{array}$ & $\begin{array}{l}\text { Log } \\
\text { transformed }\end{array}$ & $r$ \\
\hline $\begin{array}{l}\text { Asok et al. } \\
(2013)\end{array}$ & $\begin{array}{l}\text { Neglect, family } \\
\text { violence etc }\end{array}$ & 89 & 4.9 & No & $\begin{array}{l}\text { Buccal } \\
\text { mucosa }\end{array}$ & PCR & Yes & No & Yes & Yes & No & $-0.22 *$ \\
\hline $\begin{array}{l}\text { Beach et al. } \\
(2014)\end{array}$ & Life stress & 183 & 21.8 & Yes & Leukocyte & PCR & No & No & No & No & No & -0.04 \\
\hline $\begin{array}{l}\text { Bersani et al. } \\
\text { (2016) }\end{array}$ & $\begin{array}{l}\text { Abuse, } \\
\text { general } \\
\text { trauma }\end{array}$ & 76 & 34.6 & Yes & Leukocyte & PCR & No & Yes & $\begin{array}{l}\text { All } \\
\text { same } \\
\text { sex }\end{array}$ & Yes & No & $-0.43^{* *}$ \\
\hline $\begin{array}{l}\text { Chen et al. } \\
\text { Depressed } \\
(2014)\end{array}$ & $\begin{array}{l}\text { Abuse, } \\
\text { neglect etc }\end{array}$ & 20 & 35.9 & Yes & Leukocyte & PCR & No & Yes & Yes & No & No & -0.13 \\
\hline $\begin{array}{l}\text { Chen et al. } \\
\text { (2014) } \\
\text { Controls }\end{array}$ & $\begin{array}{l}\text { Abuse, } \\
\text { neglect etc }\end{array}$ & 20 & 35.9 & Yes & Leukocyte & PCR & No & Yes & Yes & No & No & $-0.61^{*}$ \\
\hline $\begin{array}{l}\text { Drury et al. } \\
(2012)\end{array}$ & $\begin{array}{l}\text { In institutional } \\
\text { care }\end{array}$ & 100 & 8.4 & No & $\begin{array}{l}\text { Buccal } \\
\text { mucosa }\end{array}$ & PCR & No & Yes & Yes & Yes & No & -0.05 \\
\hline $\begin{array}{l}\text { Drury et al. } \\
\text { (2014) }\end{array}$ & $\begin{array}{l}\text { Adverse } \\
\text { events }\end{array}$ & 80 & 10.2 & Yes & $\begin{array}{l}\text { Buccal } \\
\text { mucosa }\end{array}$ & PCR & Yes & Yes & Yes & Yes & No & $-0.28 *$ \\
\hline $\begin{array}{l}\text { Glass et al. } \\
(2010)\end{array}$ & $\begin{array}{l}\text { Physical } \\
\text { abuse, } \\
\text { sexual } \\
\text { abuse }\end{array}$ & 1090 & 47.8 & Yes & $\begin{array}{l}\text { Leukocyte } \\
\text { Southern } \\
\text { blot }\end{array}$ & & Yes & No & No & No & No & .002 \\
\hline $\begin{array}{l}\text { Jodczyk et al. } \\
\text { (2014) }\end{array}$ & $\begin{array}{l}\text { Interparent } \\
\text { violence, } \\
\text { physical } \\
\text { abuse etc }\end{array}$ & 677 & 29.0 & Yes & Leukocyte & PCR & No & All same age & Yes & Yes & No & -0.01 \\
\hline $\begin{array}{l}\text { Kananen et al. } \\
\text { (2010) }\end{array}$ & $\begin{array}{l}\text { Parental } \\
\text { substance } \\
\text { abuse/ } \\
\text { mental } \\
\text { illness etc }\end{array}$ & 974 & 49.8 & Yes & Leukocyte & PCR & No & Yes & Yes & No & Yes & $-0.09 *$ \\
\hline $\begin{array}{l}\text { Kiecolt-Glaser } \\
\text { et al. } \\
\text { (2011) }\end{array}$ & $\begin{array}{l}\text { Abuse, } \\
\text { neglect etc }\end{array}$ & 132 & 65.9 & Yes & $\begin{array}{l}\text { Leukocyte } \\
\text { Southern } \\
\text { blot }\end{array}$ & & Yes & Yes & Yes & Yes & No & -0.06 \\
\hline $\begin{array}{l}\text { Kuffer et al. } \\
(2016) \\
\text { Controls }\end{array}$ & $\begin{array}{l}\text { Abuse, } \\
\text { neglect }\end{array}$ & 58 & 71.9 & Yes & $\begin{array}{l}\text { Buccal } \\
\text { mucosa }\end{array}$ & PCR & No & Yes & Yes & No & No & 0.21 \\
\hline $\begin{array}{l}\text { Kuffer et al. } \\
\text { (2016) } \\
\text { Indentured }\end{array}$ & $\begin{array}{l}\text { Abuse, } \\
\text { neglect }\end{array}$ & 62 & 76.2 & Yes & $\begin{array}{l}\text { Buccal } \\
\text { mucosa }\end{array}$ & PCR & No & Yes & Yes & No & No & 0.12 \\
\hline $\begin{array}{l}\text { Levandowski } \\
\text { et al. } \\
(2016)^{\text {a }}\end{array}$ & $\begin{array}{l}\text { Childhood } \\
\text { adversity }\end{array}$ & 87 & 28.6 & Yes & Blood & PCR & Yes & No & All same sex & No & No & $-0.41^{* *}$ \\
\hline $\begin{array}{l}\text { Mason et al. } \\
(2015)^{\mathrm{b}}\end{array}$ & $\begin{array}{l}\text { Physical } \\
\text { abuse, } \\
\text { sexual } \\
\text { abuse }\end{array}$ & 1130 & 45.5 & Yes & Leukocyte & PCR & No & Yes & All same sex & No & Yes & -0.01 \\
\hline $\begin{array}{l}\text { O'Donovan } \\
\text { et al. } \\
(2011)\end{array}$ & $\begin{array}{l}\text { Physical } \\
\text { abuse, } \\
\text { physical } \\
\text { neglect etc }\end{array}$ & 41 & 30.2 & Yes & Leukocyte & PCR & No & Yes & No & No & No & $-0.42 *$ \\
\hline $\begin{array}{l}\text { Osler et al. } \\
\text { (2016) }\end{array}$ & $\begin{array}{l}\text { Parental } \\
\text { illness/ } \\
\text { loss, } \\
\text { separated } \\
\text { from home etc }\end{array}$ & 324 & 57.0 & Yes & Leukocyte & PCR & No & $\begin{array}{l}\text { All } \\
\text { same } \\
\text { age }\end{array}$ & $\begin{array}{l}\text { All } \\
\text { same } \\
\text { sex }\end{array}$ & No & No & -0.02 \\
\hline $\begin{array}{l}\text { Savolainen } \\
\text { et al. (2014) }\end{array}$ & $\begin{array}{l}\text { Absent } \\
\text { parent }\end{array}$ & 1486 & 61.5 & No & Leukocyte & PCR & Yes & Yes & Yes & Yes & Yes & -0.05 \\
\hline
\end{tabular}


$\mathrm{P}=0.068$, two-tailed. The association would be significant at $\mathrm{P}=0.034$ with a one-tailed test. The other moderator analyses were all categorical comparisons. Table 2 shows the results. Two variables showed significant moderation of effect size: Studies that compared groups, e.g., being abused or not, showed higher associations between level of childhood stressor and telomere length than studies that treated stressor level as a continuous variable. Also, studies that used qPCR had higher effect sizes than studies that used Southern Blot. If we apply a Bonferroni correction to control for alpha inflation in the analyses of the eight categorical variables, these findings would not meet the adjusted P standard of $0.05 / 8$ or 0.006 .

Table 1. Continued from previous page.

\begin{tabular}{|c|c|c|c|c|c|c|c|c|c|c|c|c|}
\hline Author & $\begin{array}{l}\text { Childhood } \\
\text { psychosocial } \\
\text { stressor/s }\end{array}$ & No. & $\begin{array}{l}\text { Mean } \\
\text { age at } \\
\text { telomere } \\
\text { collection }\end{array}$ & $\begin{array}{l}\text { Memory-based } \\
\text { retrospective } \\
\text { assessment } \\
\text { of stressor }\end{array}$ & $\begin{array}{l}\text { TL cell } \\
\text { type }\end{array}$ & $\begin{array}{l}\text { TL assay } \\
\text { type }\end{array}$ & $\begin{array}{l}\text { Categorical } \\
\text { stressor }\end{array}$ & $\begin{array}{l}\text { Age } \\
\text { controlled }\end{array}$ & $\begin{array}{l}\text { Sex } \\
\text { controlled }\end{array}$ & $\begin{array}{l}\text { Other } \\
\text { variables } \\
\text { controlled } \\
\text { for }\end{array}$ & $\begin{array}{l}\text { Log } \\
\text { transformed }\end{array}$ & $r$ \\
\hline $\begin{array}{l}\text { Schaakxs } \\
\text { et al . (2015) }\end{array}$ & $\begin{array}{l}\text { Adverse } \\
\text { events, } \\
\text { trauma }\end{array}$ & 496 & 70.6 & Yes & Leukocyte & PCR & $\begin{array}{l}\text { Yes for } \\
\text { adverse } \\
\text { events; } \\
\text { No for } \\
\text { trauma }\end{array}$ & Yes & Yes & Yes & No- & $0.32 * *$ \\
\hline $\begin{array}{l}\text { Shalev et al. } \\
\text { (2013) }\end{array}$ & $\begin{array}{l}\text { Family violence, } \\
\text { physical } \\
\text { abuse etc }\end{array}$ & 236 & 10.0 & No & $\begin{array}{l}\text { Buccal } \\
\text { mucosa }\end{array}$ & PCR & Yes & $\begin{array}{l}\text { All } \\
\text { same age }\end{array}$ & Yes & Yes & No & -0.05 \\
\hline $\begin{array}{l}\text { Surtees et al. } \\
\text { (2011) }\end{array}$ & $\begin{array}{l}\text { Emotional abuse, } \\
\text { physical } \\
\text { abuse etc }\end{array}$ & 4441 & 62.0 & Yes & Leukocyte & PCR & No & Yes & All same sex & No & No & -0.01 \\
\hline $\begin{array}{l}\text { Tyrka et al. } \\
\text { (2010) }\end{array}$ & $\begin{array}{l}\text { Physical neglect, } \\
\text { emotional } \\
\text { neglect }\end{array}$ & 31 & 26.9 & Yes & Leukocyte & PCR & Yes & No & No & No & No & -0.31 \\
\hline $\begin{array}{l}\text { Tyrka et al. } \\
\text { (2015) }\end{array}$ & $\begin{array}{l}\text { Parental loss, } \\
\text { separation } \\
\text { from family }\end{array}$ & 179 & 31.0 & Yes & Leukocyte & PCR & Yes & No & No & No & No & -0.09 \\
\hline $\begin{array}{l}\text { van Ockenburg } \\
\text { et al . (2015) }\end{array}$ & $\begin{array}{l}\text { Parental loss, } \\
\text { parental } \\
\text { separation etc }\end{array}$ & 445 & 55.5 & Yes & Leukocyte & PCR & No & Yes & Yes & Yes & Yes & -0.00 \\
\hline $\begin{array}{l}\text { Verhoeven } \\
\text { et al . (2015) }\end{array}$ & $\begin{array}{l}\text { Emotional } \\
\text { neglect, } \\
\text { emotional } \\
\text { abuse etc }\end{array}$ & 2936 & 41.8 & Yes & Leukocyte & PCR & $\begin{array}{l}\text { Yes for } \\
\text { parental loss } \\
\text { etc; } \\
\text { No for } \\
\text { neglect etc }\end{array}$ & Yes & Yes & Yes & No & -0.02 \\
\hline $\begin{array}{l}\text { Zalli et al. } \\
\text { (2014) }\end{array}$ & $\begin{array}{l}\text { Parental loss } \\
\text { /separation, } \\
\text { household } \\
\text { substance use etc }\end{array}$ & 434 & 63.2 & Yes & Leukocyte & PCR & Yes & Yes & Yes & Yes & No & -0.01 \\
\hline
\end{tabular}

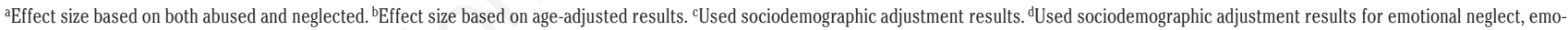
tional abuse, physical abuse, sexual abuse. ${ }^{*} \mathrm{P}<0.05,{ }^{*} \mathrm{P}<0.001$.
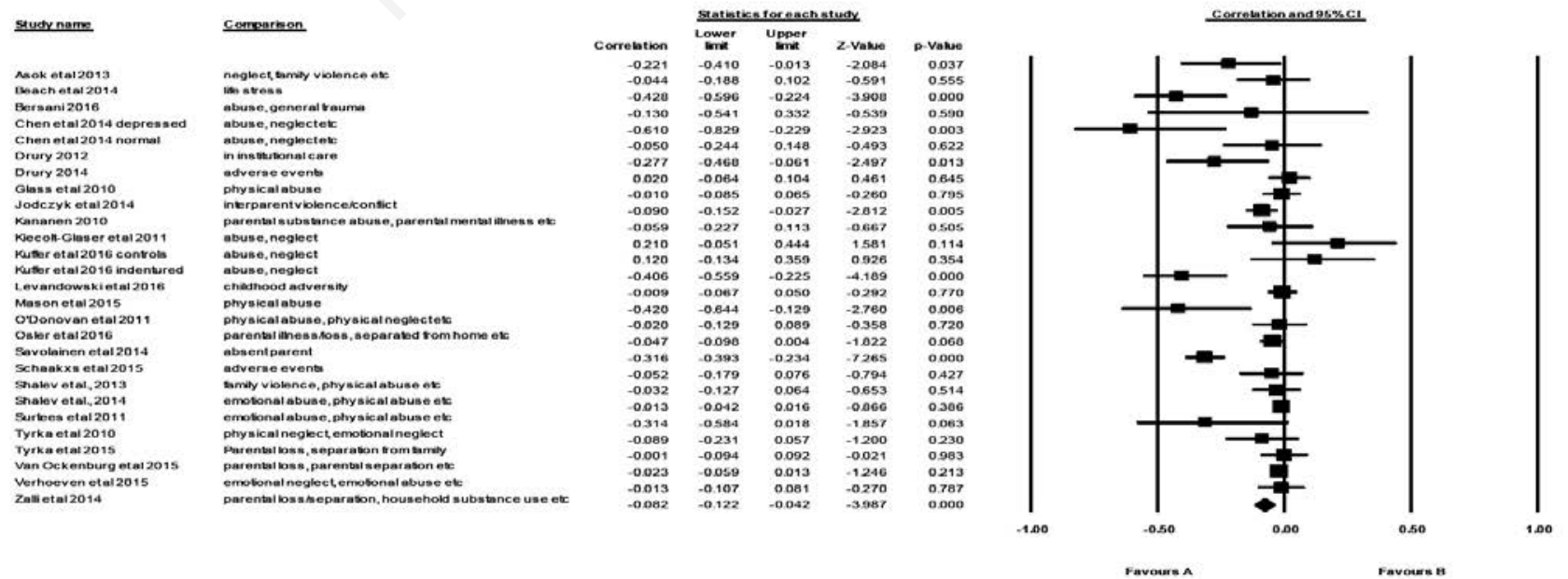

Figure 2. Graphical representation of effect size for each sample. 


\section{Discussion and Conclusions}

The meta-analysis found a small but significant association (0.08 ) between level of childhood psychosocial stressors and telomere length, across 27 samples that included 16,238 participants. The association was significant regardless of whether stressor level was based on recall or more objective documentation, and regardless of whether the cells assayed for telomere length were leukocytes or buccal. Childhood stressors can have a long-term impact on telomere length, as indicated by the significant association between exposure to childhood stressors and telomere length at a mean age of 42 years for participants included in the present metaanalysis.

The results provide a possible mediational explanation for the finding that psychosocial stressors experienced during childhood predict negative health outcomes in adulthood (Felitti et al., 1998; Shonkoff \& Garner, 2012; Wegman \& Stetler, 2009). There are a number of biological and behavioural pathways that early trauma affects, such as inflammation and changes in health behaviours, and these also interact with telomere length; thus the causal factors linking early trauma and later disease are likely due to a variety of inter-related factors. (Danese \& McEwens, 2012). Telomere length appears to be one of the causal factors, as recent mendelian genetic studies of telomere length have shown direct prediction of earlier onset of certain diseases of aging (Codd et al., 2013; Zhan et al., 2015).

The findings of the present meta-analysis extend findings of previous research on psychological states and telomere length in focusing on the relationship between actual events experienced in childhood and later telomere length. Prior meta-analyses reported significant associations between perceived stress and telomere length (Mathur et al., 2016; Schutte \& Malouff, 2014). Prior metaanalyses also found significant associations between anxiety levels and telomere length (Malouff \& Schutte, in press) and between depression and telomere length (Schutte \& Malouff, 2015). Childhood psychosocial stressors predict telomere shortening, and negative psychological states (perceived stress, anxiety, and depression) may operate as mediators linking stressors and telomere shortening. Some studies have found that recent psychosocial stressors in adults are also associated with shorter telomeres (e.g., Schaakxs et al., 2015). Telomere functioning is dynamic (Blackburn et al., 2015) and shortened telomeres may recover as time passes after exposure to a stressor (Verhoeven et al., 2015), and thus we predicted that time would moderate effect size. We found a moderation trend consistent with this view. However, remarkably, childhood stressors were still significantly associated with shortened telomeres decades later. It is unknown whether childhood psychosocial stressors are more or less associated with telomere length than stressors experienced by adults, but it is possible that childhood stressors have more impact because childhood is a critical period of development of biological systems (Shonkoff \& Garner, 2012) or because of the limited coping ability of children. Studies have found exposure to other environmental factors, such as pesticides, to be associated with telomere length (Hou et al., 2013). The present findings add meta-analytic results for earlylife psychosocial environmental factors. One interesting meta-ana-

Table 2. Categorical moderator analysis.

\begin{tabular}{|c|c|c|c|c|c|c|c|c|}
\hline \multirow[t]{2}{*}{ Moderator } & \multirow[t]{2}{*}{$k$} & \multirow[t]{2}{*}{$r$} & \multicolumn{3}{|c|}{ CI $95 \%$} & \multicolumn{3}{|c|}{ Homogeneity Analysis } \\
\hline & & & Lower & Upper & $\mathbf{P}$ & Q & df & P \\
\hline \multicolumn{9}{|c|}{ Memory-based retrospective assessment of stressor $^{1} \mathrm{Q}(1)=1.01, \mathrm{P}=0.32$} \\
\hline No & 4 & -0.06 & -0.1 & -0.01 & 0.02 & 2.57 & 3 & 0.46 \\
\hline Yes & 22 & -0.09 & -0.14 & -0.04 & $<0.001$ & 105.96 & 21 & $<0.001$ \\
\hline \multicolumn{9}{|c|}{ TL cell type ${ }^{2} Q(1)=0.04, P=0.84$} \\
\hline Buccal & 6 & -0.06 & -0.19 & 0.07 & 0.39 & 12.25 & 5 & 0.03 \\
\hline Leukocyte & 20 & -0.07 & -0.11 & -0.03 & $<0.001$ & 81.97 & 19 & $<0.001$ \\
\hline \multicolumn{9}{|c|}{ TL assay type, $Q(1)=4.49, \mathrm{P}=0.03$} \\
\hline Southern blot & 2 & 0.01 & -0.07 & 0.08 & 0.90 & 0.64 & 1 & \\
\hline qPCR & 25 & -0.10 & -0.13 & -0.05 & $<0.001$ & 106.77 & 24 & $<0.001$ \\
\hline \multicolumn{9}{|c|}{ Categorical stressor $Q(1)=4.39, P=0.04$} \\
\hline Yes & 11 & -0.14 & -0.23 & -0.06 & $<0.001$ & 57.19 & 10 & $<0.001$ \\
\hline No & 16 & -0.04 & -0.08 & -0.00 & 0.04 & 38.59 & 15 & 0.001 \\
\hline \multicolumn{9}{|c|}{ Age controlled $Q(2)=4.95, \mathrm{P}=0.08$} \\
\hline All same age & 4 & -0.02 & -0.07 & 0.03 & 0.34 & 0.35 & 3 & 0.95 \\
\hline No & 6 & -0.15 & -0.28 & -0.02 & 0.03 & 21.00 & 5 & $<0.001$ \\
\hline Yes & 17 & -0.09 & -0.14 & -0.03 & $<0.001$ & 85.81 & 16 & $<0.001$ \\
\hline \multicolumn{9}{|c|}{ Sex controlled $Q(1)=0.32, P=0.85$} \\
\hline All same sex & 6 & -0.10 & -0.18 & -0.01 & 0.02 & 30.19 & 5 & $<0.001$ \\
\hline No & 5 & -0.11 & -0.23 & 0.02 & 0.10 & 11.34 & 4 & 0.02 \\
\hline Yes & 16 & -0.08 & -0.13 & -0.02 & 0.01 & 63.91 & 15 & $<0.001$ \\
\hline \multicolumn{9}{|c|}{ Other variables controlled for $Q(1)=0.89, \mathrm{P}=0.35$} \\
\hline No & 15 & -0.06 & -0.12 & -0.01 & 0.02 & 44.62 & 14 & $<0.001$ \\
\hline Yes & 12 & -0.10 & -0.17 & -0.04 & $<0.01$ & 61.35 & 11 & $<0.001$ \\
\hline \multicolumn{9}{|c|}{ Log transformed $Q(1)=3.39, \mathrm{P}=0.07$} \\
\hline Yes & 4 & -0.04 & -0.08 & 0.00 & 0.03 & 4.29 & 3 & 0.23 \\
\hline No & 23 & -0.10 & -0.15 & -0.05 & $<0.001$ & 104.67 & 22 & $<0.001$ \\
\hline
\end{tabular}

Shalev et al. (2014) excluded because study used mixed methods. ${ }^{2}$ Levandowski et al. (2016) excluded because study used "blood." 


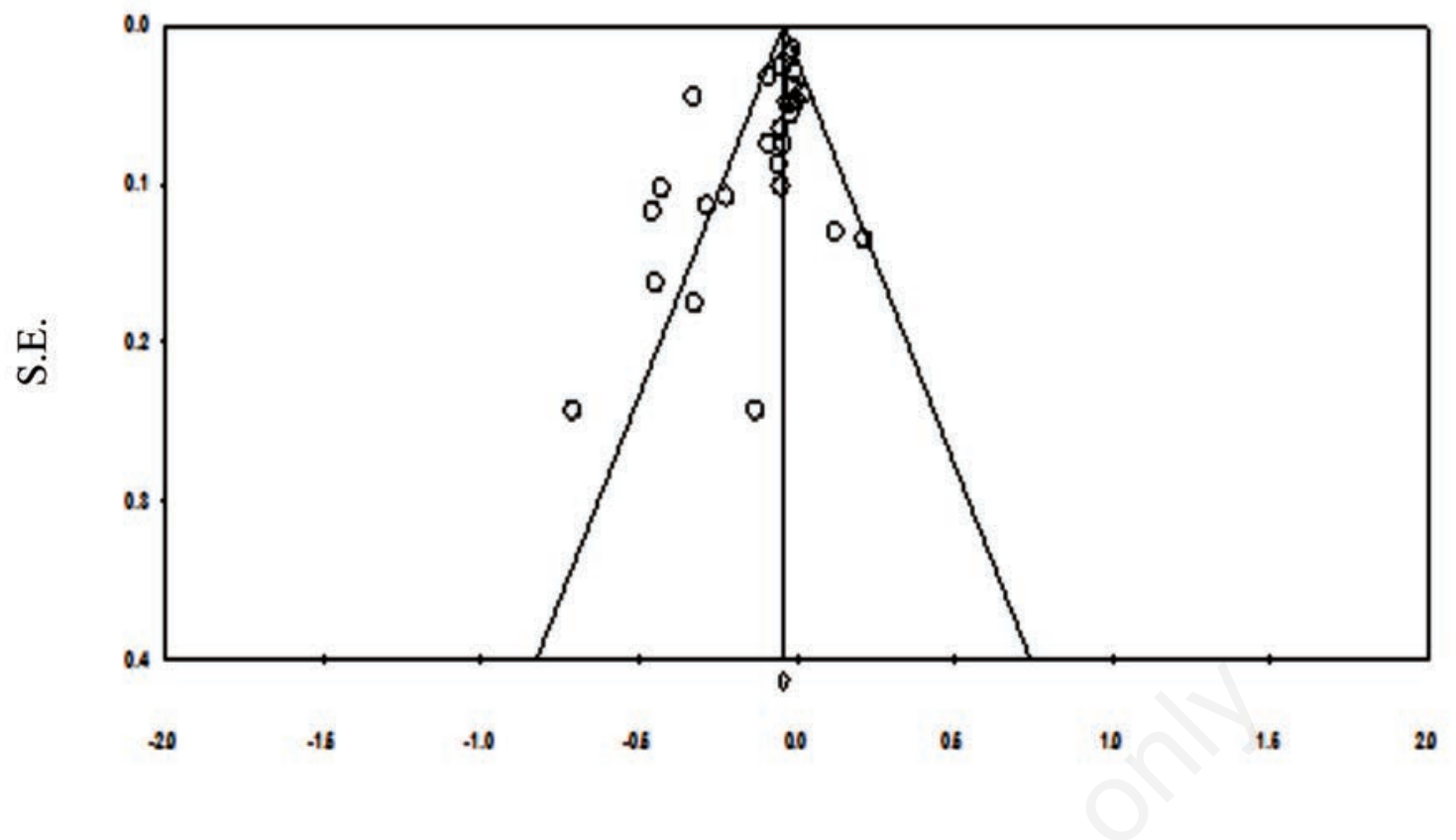

Fisher's Z

Figure 3. Funnel plot of standard error by effect size (Fisher's Z).

lytic moderator finding involved the significantly greater effect size for comparison of extreme groups on level of childhood stressors than for correlational studies with various levels of stressors. Similarly, a meta-analysis of the association between anxiety level and telomere length found that analyses of extreme groups showed much greater effect sizes than correlational studies, although the difference was not significant (Malouff \& Schutte, 2016). It could be that only extreme levels of childhood psychosocial stressors have long-term effects on telomere length.

Studies that used qPCR assays had significantly higher effect sizes than Southern blot studies. Because only two studies in the meta-analysis used Southern blot, that finding may be a statistical fluke.

The moderator results are best viewed as suggestive. First, with only 27 samples included, the moderator analyses had limited power to identify significant differences. Second, moderator analyses are always quasi-experimental - no one randomly assigned some studies to use one method and other studies to use another. Third, the statistical significance of some moderators in this metaanalysis varies with how conservative one wants to be regarding using one-tailed tests and controlling for alpha inflation

Future research on child psychosocial stressors and telomere length might systematically compare different types of psychosocial stressors and examine the role of possible mediators and moderators, including potential buffers such as social support. In addition, it will be important to examine in more depth the characteristics of the stressors and symptoms of distress. This type of research will help identify both predictors of vulnerability and resilience to the lifelong effects of severe childhood stressors.

\section{References}

Adams, J., Martin-Ruiz, C., Pearce, M.S., White, M., Parker, L., \& von Zglinicki, T. (2007). No association between socio-economic status and white blood cell telomere length. Aging Cell, $6,125-128$.

Blackburn, E.H., Epel, E.S., \& Lin, J. (2015). Human telomere biology: a contributory and interactive factor in aging, disease risks, and protection. Science, 350(6265), 1193-1198. doi:10.1126/science.aab3389

Borenstein, M., Hedges, L., Higgins, J., \& Rothstein, H. (2014). Comprehensive meta-analysis (Version 3) [computer software]. Englewood, NJ: Biostat.

Brody, G.H., Yu, T., Beach, S.R., \& Philibert, R.A. (2015). Prevention effects ameliorate the prospective association between nonsupportive parenting and diminished telomere length. Society for Prevention Research, 16, 171-180. doi:10.1007/x11121-014-0474-2

Brown, D.W., Anda, R.F., Tiemeier, H., Felitti, V.J., Edwards, V.J., Croft, J.B., \& Giles, W.H. (2009). Adverse childhood experiences and the risk of premature mortality. American Journal of Preventive Medicine, 37, 389-396. doi:10.1016/j.amepre.2009.06.021

Carroll, J.E., Diez-Roux, A.V., Adler, N.E., \& Seeman, T.E. (2013). Socioeconomic factors and leukocyte telomere length in a multi-ethnic sample: Findings from The Multi-Ethnic Study of Atherosclerosis (MESA). Brain, Behavior and Immunity, 28, 108-114. doi:10.1016/j.bbi.2012.10.024

Chen, S.H., Epel, E.S., Mellon, S.H., Lin, J., Reus, V.I., Rosser, R., .. Wolkowitz, O.M. (2014). Adverse childhood experiences and leukocyte telomere maintenance in depressed and healthy adults. Journal of Affective Disorders, 169, 86-90. 
doi:10.1016/j.jad.2014.07.035

Codd, V., Nelson, C.P., Albrecht, E., Mangino, M., Deelen, J., Buxton, J.L., ... \& Broer, L. (2013). Identification of seven loci affecting mean telomere length and their association with disease. Nature Genetics, 45, 422-427. doi: 10.1038/ng.2528

Cohen, S., Janicki-Deverts, D., Turner, R.B., Marsland, A.L., Casselbrant, M.L., Li-Korotky, H.S., ..., Doyle, W.J. (2013). Childhood socioeconomic status, telomere length, and susceptibility to upper respiratory infection. Brain, Behaviour \& Immunity, 34, 31-38. doi:10.1016/j.bbi.2013.06.009

Danese, A., \& McEwen, B.S. (2012). Adverse childhood experiences, allostasis, allostatic load, and age-related disease. Physiology \& behavior, 106, 29-39. doi: org/10.1016/j.physbeh.2011.08.019

Drury, S.S., Mabile, E., Brett, Z.H., Esteves, K., Jones, E., Shirtcliff, E.A., \& Theall, K.P. (2014). The association of telomere length with family violence and disruption. Pediatrics, 134, e128. doi:10.1542/peds.2013-3415

Epel, E. (2012). How "reversible" is telomeric aging?. Cancer Prevention Research, 5, 1163-1168. doi: 0.1158/19406207.CAPR-12-0370

Felitti, V.J., Anda, R.F., Nordenberg, D., Williamson, D.F., Spitz, A.M., Edwards, V., ..., Marks, J.S. (1998). Relationship of childhood abuse and household dysfunction to many of the leading causes of death in adults. American Journal of Preventative Medicine, 14, 245-258. doi:10.1016/S07493797(98)00017-8

Gardner, M., Bann, D., Wiley, L., Cooper, R., Hardy, R., Nitsch, D., ..., \& Bekaert, S. (2014). Gender and telomere length: systematic review and meta-analysis. Experimental Gerontology, $51,15-27$

Glass, D., Parts, L., Knowles, D., Aviv, A., \& Spector, T.D. (2010). No correlation between childhood maltreatment and telomere length. Biological Psychiatry, 68, e21-e22. doi:10.1016/j.biopsych.2010.02.026

Green, J.G., McLaughlin, K.A., Berglund, P.A., Gruber, M.J., Sampson, N.A., Zaslavsky, A.M., \& Kessler, R.C. (2010). Childhood adversities and adult psychopathology in the National Comorbidity Survey Replication (NCS-R) I: associations with first onset of DSM-IV disorders. Archives of General Psychiatry, 67, 113. doi:10.1001/archgenpsychiatry.2009.186

Hou, L., Andreotti, G., Baccarelli, A.A., Savage, S., Hoppin, J.A., Sandler, D.P., ..., \& Zhang, X. (2013). Lifetime pesticide use and telomere shortening among male pesticide applicators in the agricultural health study. Environmental health perspectives, 121, 919. doi: 10.1289/ehp.1206432

Jodczyk, S., Fergusson, D.M., Horwood, L.J., Pearson, J.F., \& Kennedy, M.A. (2014). No association between mean telomere length and life stress observed in a 30 year birth cohort. PLoS ONE, 9, e97102. doi:10.1371/journal.pone.0097102

Kananen, L., Surakka, I., Pirkola, S., Suvisaari, J., Lönnqvist, J., Peltonen, L., ..., Hovatta, I. (2010). Childhood adversities are associated with shorter telomere length at adult age both in individuals with an anxiety disorder and controls. PLOS ONE, 5, e10826. doi:10.1371/journal.pone.0010826

Küffer, A.L., Maercker, A., Burri, A., \& O’Donovan, A. (2016). Post-traumatic stress disorder, adverse childhood events and buccal cell telomere length in elderly Swiss former indentured child laborers. Frontiers in Psychiatry, 7, 147. doi:10.3389/fpsyt.2016.00147

Levandowski, M.L., Tractenberg, S.G., de Azeredo, L.A., De Nardi, T., Rovaris, D.L., Bau, C.H., . . \& \& Grassi-Oliveira, R.
(2016). Crack cocaine addiction, early life stress and accelerated cellular aging among women. Progress in NeuroPsychopharmacology and Biological Psychiatry, 71, 83-89. doi:10.1016/j.pnpbp.2016.06.009

Malouff, J.M., \& Schutte, N.S. (in press). A meta-analysis of the relationship between anxiety and telomere length. Anxiety, Stress, \& Coping.

Marioni, R.E., Harris, S.E., Shah, S., McRae, A.F., von Zglinicki, T., Martin-Ruiz, C., ..., \& Deary, I.J. (2016). The epigenetic clock and telomere length are independently associated with chronological age and mortality. International Journal of Epidemiology, 45, 424-432. doi: 10.1093/ije/dyw041

Mason, S.M., Prescott, J., Tworoger, S.S., DeVivo, I., \& RichEdwards, J.W. (2015). Childhood physical and sexual abuse history and leukocyte telomere length among women in middle adulthood. PLoS ONE, 10, e0124493. doi:10.1371/journal.pone.0124493

Mathur, M.B., Epel, E., Kind, S., Desai, M., Parks, C.G., Sandler, D.P., \& Khazeni, N. (2016). Perceived stress and telomere length: A systematic review, meta-analysis, and methodologic considerations for advancing the field. Brain, Behavior, and Immunity, 54, 158-169. doi: org/10.1016/j.bbi.2016.02.002

Mitchell, C., Hobcraft, J., McLanahan, S.S., Siegel, S.R., Berg, A., Brooks-Gunn, J., ..., \& Notterman, D. (2014). Social disadvantage, genetic sensitivity, and children's telomere length. Proceedings of the National Academy of Sciences, 111, 59445949. doi: 10.1073/pnas.1404293111

Næss, A.B., \& Kirkengen, A.L. (2015). Is childhood stress associated with shorter telomeres?. Tidsskrift for den Norske laegeforening: tidsskrift for praktisk medicin, ny raekke, 135, 13561360. doi: 10.4045/tidsskr.14.1194

Needham, B.L., Fernandez, J.R., Lin, J., Epel., E.S., \& Blackburn, E.H. (2012). Socioeconomic status and cell aging in children. Social Science \& Medicine, 74, 1948-1951. doi:10.1016/j.socscimed.2012.02.019

O’Donovan, A., Epel, E., Lin, J., Wolkowitz, O., Cohen, B., Maguen, S., ..., Neylan, T.C. (2011). Childhood trauma associated with short leukocyte telomere length in post-traumatic stress disorder. Biological Psychiatry, 70, 465-471. doi:10.1016/j.biopsych.2011.01.035

Oliveira, B.S., Zunzunegui, M.V., Quinlan, J., Fahmi, H., Tu, M.T., \& Guerra, R.O. (2016). Systematic review of the association between chronic social stress and telomere length: a life course perspective. Ageing Research Reviews, 26, 37-52. doi: org/10.1016/j.arr.2015.12.006

Osler., M., Bendix, L., Rask, L., Rod, N.H. (in press). Stressful life events and leukocyte telomere length: do lifestyle factors, somatic and mental health, or low grade inflammation mediate this relationship? Results from a cohort of Danish men born in 1953. Brain, Behaviour, and Immunity. doi:10.1016/j.bbi.2016.07.154

Révész, D., Milaneschi, Y., Terpstra, E.M., \& Penninx, B.W.J.H. (2016). Baseline biopsychosocial determinants of telomere length and 6-year attrition rate. Psychoneuroendocrinology, 67, 153-162. doi:10.1016/j.psyneuen.2016.02.007

Rode, L., Nordestgaard, B.G., \& Bojesen, S.E. (2015). Peripheral blood leukocyte telomere length and mortality among 64637 individuals from the general population. Journal of the National Cancer Institute, 107, djv074. doi: 10.1093/jnci/djv074

Robertson, T., Batty, G.D., Der, G., Green, M.J., McGlynn, L. M., McIntyre, A., ..., Benzeval, M. (2012). Is telomere length socially patterned? Evidence from the West of Scotland 
Twenty-07 Study. PLoS ONE, 7, e41805. doi:10.1371/journal.pone.0041805

Robles, T.F., Carroll, J.E., Bai, S., Reynolds, B.M., Esquivel, S., \& Repetti, R.L. (2016). Emotions and family interactions in childhood: association with leukocyte telomere length. Psychoneuroendocrinology, 63, 343-350. doi:10.1016/j.psyneuen.2015.10.018

Savolainen, K., Eriksson, J.G., Kananen, L., Kajantie, E., Pesonen, A., Heinonen, K., \& Räikkönen, K. (2014). Associations between early life stress, self-reported traumatic experiences across the lifespan and leukocyte telomere length in elderly adults. Biological Psychology, 97, 35-42. doi:10.1016/j.biopsycho.2014.02.002

Schaakxs, R., Wielaard, I., Verhoeven, J.E., Beekman, A.T.F., Penninx, B.W.J.H., \& Comijs, H.C. (2015). Early and recent psychosocial stress and telomere length in older adults. International Psychogeriatrics, 28, 405-413. doi:10.1017/S1041610215001155

Schutte, N.S., \& Malouff, J.M. (2015). The association between depression and leukocyte telomere length: a meta $\square$ analysis. Depression and Anxiety, 32, 229-238.

Schutte, N.S., \& Malouff, J.M. (2016). The relationship between perceived stress and telomere length: a meta $\square$ analysis. Stress and Health, 32, 313-319. doi: 10.1002/smi.2607

Shalev, I., Moffitt, T.E., Braithwaite, A.W., Danese, A., Fleming, N.I., Goldman-Mellor, S., ..., Caspi, A. (2014). Internalizing disorders and leukocyte telomere erosion: a prospective study of depression, generalized anxiety disorder and post-traumatic stress disorder. Molecular Psychiatry, 19, 1163-1170. doi:10.1038/mp.2013.183

Shalev, I., Moffitt, T.E., Sugden, K., Williams, B., Houts, R.M., Danese, A., ..., Caspi, A. (2013). Exposure to violence during childhood is associated with telomere erosion from 5 to 10 years of age - A longitudinal study. Molecular Psychiatry, 18, 576-581. doi:10.1038/mp.2012.32

Shonkoff, J.P., Boyce, W.T., \& McEwen, B.S. (2009). Neuroscience, molecular biology, and the childhood roots of health disparities: building a new framework for health promotion and disease prevention. JAMA, 301, 2252-2259. doi:10.1001/jama.2009.754

Shonkoff, J.P., \& Garner, A.S. (2012). Committee on Psychosocial Aspects of Child and Family Health; Committee on Early Childhood, Adoption, and Dependent Care; Section on Developmental and Behavioral Pediatrics. The lifelong effects of early childhood adversity and toxic stress. Pediatrics, 129 , e232-e246. doi:10.1542/peds.2011-2663

Surtees, P.G., Wainwright, N.W.J., Pooley, K.A., Luben, R.N., Khaw, K., Easton, D.F., \& Dunning, A.M. (2011). Life stress, emotional health, and mean telomere length in the European
Prospective Investigation into Cancer (EPIC)-Norfolk population study. The Journals of Gerontology Series A: Biological Sciences and Medical Sciences, 66A, 1152-1162. doi:10.1093/gerona/glr112

Theall, K.P., Brett, Z.H., Shirtcliff, E.A., Dunn, E.C., \& Drury, S.S. (2013). Neighborhood disorder and telomeres: Connecting children's exposure to community level stress and cellular response. Social Science \& Medicine, 85, 50-58. doi:10.1016/j.socscimed.2013.02.030

Tyrka, A.R., Parade, S.H., Price, L.H., Kao, H.T., Porton, B., Philip, N.S., . . . Carpenter, L.L. (2015). Alterations of mitochondrial DNA copy number and telomere length with early adversity and psychopathology. Biological Psychiatry, 79, 7886. doi:10.1016/j.biopsych.2014.12.025

Tyrka, A.R., Price, L.H., Kao, H., Porton, B., Marsella, S.A., \& Carpenter, L.L. (2010). Childhood maltreatment and telomere shortening: Preliminary support for an effect of early stress on cellular aging. Biological Psychiatry, 67, 531-534. doi:10.1016/j.biopsych.2009.08.014

van Ockenburg, S.L., Bos, E.H., de Jonge, P., van der Harst, P., Gans, R.O.B., \& Rosmalen, J.G.M. (2015). Stressful life events and leukocyte telomere attrition in adulthood: a prospective population based cohort study. Psychological Medicine, 45, 2975-2984. doi:10.1017/S0033291715000914

Verhoeven, J.E., van Oppen, P., Puterman, E., Elzinga, B., \& Penninx, B.W.J.H. (2015). The association of early and recent psychosocial life stress with leukocyte telomere length. Psychosomatic Medicine, 77, 882-891. doi:10.1097/PSY.0000000000000226

Wegman, H.L., \& Stetler, C. (2009). A meta-analytic review of the effects of childhood abuse on medical outcomes in adulthood. Psychosomatic Medicine, 71, 805-812. doi: 10.1097/PSY.0b013e3181bb2b46

Zalli, A., Carvalho, L.A., Lin, J., Hamer, M., Erusalimsky, J.D., Blackburn, E.H., \& Steptoe, A. (2014). Shorter telomeres with high telomerase activity are associated with raised allostatic load and impoverished psychosocial resources. PNAS, 111, 4519-4524. doi:10.1073/pnas.1322145111

Zhan, Y., Song, C., Karlsson, R., Tillander, A., Reynolds, C.A., Pedersen, N.L., \& Hägg, S. (2015). Telomere length shortening and Alzheimer disease: a Mendelian randomization study. JAMA Neurology, 72, 1202-1203. doi: 10.1001/jamaneurol.2015.1513

Zhang, L., Hu, X-Z., Benedek, D.M., Fullerton, C.S., Forsten, R.D., Naifeh, J.A., ..., Ursano, R.J. (2014). The interaction between stressful life events and leukocyte telomere length is associated with PTSD. Molecular Psychiatry, 19, 855-856. doi:10.1038/mp.2013.141 